\title{
PENERAPAN MODEL PBL(PROBLEM BASED LEARNING) UNTUK MENINGKATKAN AKTIVITAS DAN HASIL BELAJAR SISWA PADA MATA PELAJARAN IPA MATERI ENERGI BUNYI KELAS IV SEMESTER II DI SDN I SEDAYULAWAS BRONDONG LAMONGAN TAHUN PELAJARAN 2015/2016
}

\author{
Anggun Winata \\ Universitas PGRI Ronggolawe Tuban \\ anggunwinata@gmail.com
}

\begin{abstract}
Abstrak
Permasalahan yang terjadi di kelas IV SDN I Sedayulawas Brondong Lamongan adalah rendahnya hasil belajar yang ditandai dengan rendahnya nilai tes hasil belajar siswa.Sebagian besar siswa kelas IV belum bisa mencapai Kriteria Ketuntasan Minimal (KKM).Proses pembelajaran dapat berhasil jika didukung oleh model pembelajaran yang tepat. Salah satunya melalui model pembelajaran PBL (Problem Based Learning). Tujuan penelitian ini yaitu mengetahui peningkatan hasil belajar, aktivitas,dan respon siswamelalui penerapan model PBL (Problem Based Learning) pada mata pelajaran IPA materi energi bunyi kelas IV semester II di SDN I Sedayulawas Brondong Lamongan tahun pelajaran 2015/2016.Jenis penelitian ini merupakan Penelitian Tindakan Kelas (PTK) dilakukan dalam dua siklus. Instrumen penelitian yang digunakan adalah instrumen pembelajaran meliputi silabus, RPP, lembar kerja siswa, lembar evaluasi, lembar observasi pengajar,lembar observasi siswa dan angket.Peningkatan aktivitas siswa melalui penerapan model PBL pada mata pelajaran IPA materi energi bunyi kelas IV semester II di SDN I Sedayulawas Brondong Lamongan pada siklus I yang dapat diamati oleh observer sebesar $75 \%$ dan mengalami peningkatan pada siklus II yaitu sebesar $100 \%$.
\end{abstract}

Kata Kunci :PBL, aktivitas, hasil belajar siswa.

\section{PENDAHULUAN}

Ilmu Pengetahuan Alam (IPA) pada hakekatnya adalah ilmu yang memiliki konsep pembelajaran alam dan mempunyai hubungan yang sangat luas dengan kehidupan manusia (Maimunah, 2013:2). Sedangkan Menurut Peraturan Menteri Pendidikan Nasional (2006:484), IPA merupakan mata pelajaran yang berkaitan dengan cara mencari tahu tentang alam secara sistematis. Pembelajaran IPA di SDN I Sedayulawas Brondong Lamongan masih berlangsung secara konvensional dengan mengandalkan metode ceramah dan hafalan.Pembelajaran yang hanya mengandalkan ceramah dan hafalan cenderung kurang menarik dan membosankan bagi siswa. Pembelajaran dengan cara mendengarkan ceramah dan sesekali mencatat apa yang dikatakan oleh guru akan membuat siswa jenuh. Jika siswa jenuh maka tujuan pembelajaran tidak dapat disampaikan dengan baik.

Permasalahan yang terjadi di kelas IV SDN I Sedayulawas Brondong Lamongan adalah rendahnya hasil belajar yang ditandai dengan rendahnya nilai tes hasil belajar siswa.Sebagian besar siswa kelas IV SDN I Sedayulawas Brondong Lamongan masih belum bisa mencapai Kriteria Ketuntasan Minimal (KKM). Hal ini dibuktikan dengan rata-rata nilai siswa kelas IV di SDN I Sedayulawas Brondong Lamongan pada mata pelajaran IPA adalah 65 sedangkan KKM yang ditetapkan untuk mata pelajaran IPA adalah 
70. Sejumlah 20 siswa hanya 8 siswa yang mampu mencapai KKM. Hal ini membuktikan bahwa model pembelajaran yang digunakan dalam pembelajaran IPA selama ini masih belum dapat meningkatkan hasil belajar siswa.

Berdasarkan hasil observasi, rendahnya ketuntasan yang dicapai siswa disebabkan oleh guru cenderung menggunakan metode ceramah saat memberikan penjelasan dan contoh-contoh yang diperoleh dari sumber balajar buku paket. Kegiatan tersebut membuat siswa bosan dan tidak konsentrasi dengan materi yang dipelajari.Selain itu, proses pembelajaran yang membuat siswa aktif terlibat dalam pembelajaran dan pemberian permasalahan untuk dianalisis masih belum terlihat.Kondisi tersebut kurang sesuai dengan karakteristik pembelajaran IPA yang melibatkan siswa secara aktif dalam kegiatan pembelajaran untuk menemukan atau menerapkan sendiri ide-idenya dalam kehidupan sehari-hari.Salah satu materi IPA di SD kelas IV yang dekat dengan kehidupan siswa adalah materi energi.

Wartono (2010 : 7) mengatakan bahwa proses pembelajaran IPA menekankan pada pemberian pengalaman langsung untuk mengembangkan kompetensi agar menjelajahi dan memahami alam sekitar secara ilmiah yang dapat di kaitkan dengan kehidupan sehari-hari. Hal ini bertujuan agar siswa dapat memiliki konsep IPA yang bermanfaat dan dapat di terapkan dalam kehidupan sehari-hari, mengembangkan rasa ingin tahu, sikap positif terhadap lingkungan yang ada di alam sekitar. Materi energi merupakan salah satu matrei IPA yang dipelajaridi SD. Banyak contoh dari akibat yang ditunjukkan dari energi bunyi yang dapat di kaitkan dengan kehidupan sehari-hari misalnya gitar yang dipetik, genđang yang dipukul dan terompet yang ditiup dan yang lainnya.Materi energi bunyi tidak tepat jika dilakukan dengan metode ceramah dan hafalan. Materi energi bunyi lebih tepat dibelajarkan dengan model pembelajaran yang dapat membuat siswa terlibat aktif secara langsung dan melihat akibat dari adanya energi dengan pemberian masalah yang ada di lingkungan sekitar.

Barrow dalam (Barret, 2005:1) mendefinisikan PBL sebagai "The learning that results from the process of working towards the understanding of a resolution of a problem. The problem is encountered first in the learning process." Sementara Chasman et.al. (2003:1) mendefiniskan PBL sebagai “...Problem-based learning (PBL) has been defined as a teaching strategy that "simultaneously develops problem-solving strategies, disciplinary knowledge, and skills by placing students in the active role as problem-solvers confronted with a structured problem which mirrors real-world problems". Jadi, PBL adalah suatu model pembelajaran yang mengguanakan masalah dunia nyata sebagai suatu konteks bagi peserta didik untuk belajar tentang cara berpikir kriris dan keterampilan pemecahan masalah, serta untuk memperoleh pengetahuan dan konsep yang esensial dari materi pelajaran. Model PBL mengajak siswa agar mampu melatih kemampuan siswa dalam memecahkan masalah sehingga dapat meningkatkan pembelajaran yang efektif. Sejalan dengan itu, Dochy et al. (2003:542) menyatakan bahwa siswa yang diajarkan dengan Model PBL lebih baik dalam menerapkanpengetahuan dan keterampilan siswa.

Model PBL sangat tepat dígunakan untuk mengajarkan energi buryi.Hal ini disebabkan karena materi energi bunyi adalah materi yang secara kontekstual dan dekat dengan kehidupan siswa. Hung et al. (2011:486) yang-menyatakan bahwa model PBL merupakan model yang inovatif untuk mempersiapkan siswa dalam memecahkan masalah dalam proses pembelajaran di masalah kehidupan nyata.

Model PBL juga merupakan salah satu model pembelajaran aktif, dimana siswa dilibatkan secara langsung dalam proses 
pembelajaran. Model PBL menuntut siswa belajar berpikir kritis karena pada dasarnya model pembelajaran dimulai dengan aktivitas berpikir siswa mengenai materi yang akan disajikan oleh guru.Selain itu, model PBL mempunyai tujuan yaitu untuk meningkatkan pembelajaran dengan mengharuskan siswa untuk memecahkan masalah yang ada di lingunkungan sekitar. Sejalan dengan itu, Model PBL didasarkan pada pembelajaran aktif dalam kelompok kecil dengan pemberian masalah yangdigunakan sebagaistimulus untuk belajar(Colliver, 2000: 259).

Model PBL memiliki gagasan bahwa pembelajaran dapat dicapai jika kegiatan pendidikan dipusatkan pada tugas-tugas atau permasalahan yang otentik, relevan, dan dipresentasikan dalam suatu konteks. Cara tersebut bertujuan agar siswa memilki pengalaman sebagaiamana nantinya mereka hadapi di kehidupan profesionalnya.Pengalaman tersebut sangat penting karena pembelajaran yang efektif dimulai dari pengalaman konkrit.Pertanyaan, pengalaman, formulasi, serta penyususan konsep tentang pemasalahan yang mereka ciptakan sendiri merupkan dasar untuk pembelajaran. Hal ini sejalan dengan Hung et al. (2011:486) yang menyatakan bahwa PBL merupakan pembelajaran yangmemulai belajar siswa dengan menciptakan kebutuhan untukmemecahkan masalah otentik.

Berdasarkan teori yang dikembangkan Barrow dalam Liu (2005: 8-10) menjelaskan karakteristik dari PBL, yaitu : (1)Learning is student-centered, proses pembelajaran dalam PBL lebih menitikberatkan kepada siswa sebagai orang belajar sehingga PBL didukung juga oleh teori konstruktivisme dimana siswa didorong untuk dapat mengembangkan pengetahuannya sendiri (2) Authentic problems form the organizing focus for learning, masalah yang disajikan kepada siswa adalah masalah yang otentik sehingga siswa mampu dengan mudah memahami masalah tersebut serta dapat menerapkannya dalam kehidupan profesionalnya nanti (3) New information is acquired through self-directed learning, proses pemecahan masalah mungkin saja siswa belum mengetahui dan memahami semua pengetahuan prasyaratnya sehingga siswa berusaha untuk mencari sendiri melalui sumbernya seperti buku atau informasi lainnya (4) Learning occurs in small groups, agar terjadi interaksi ilmiah dan tukar pemikiran dalam usaha membangun pengetahuan secara kolaborative, maka PBL dilaksakan dalam kelompok kecilyang dibuat menuntut pembagian tugas yang jelas dan penetapan tujuan yang jelas (5) Teachers act as facilitators, guru hanya berperan sebagai fasilitator. Namun, walaupun begitu guru harus selalu memantau perkembangan aktivitas siswa dan mendorong siswa agar mencapai target yang hendak dicapai. Model PBL terdiri dari enam tahap sebagai berikut (Barret, 2005: 316).

1. Siswa diberi permasalahan oleh guru (atau permasalahan diungkap dari pengalaman siswa)

2. Siswa melakukan diskusi dalam kelompok kecil dan melakukan klarifikasi kasus permasalahan yang diberikan, mendefinisikan masalah, melakukan tukar pikiran berdasarkan pengetahuan yang mereka miliki, menetapkan hal-hal yang diperlukan untuk menyelesaikan masalah, menetapkan hal-hal yang harus dilakukan untuk menyelesaikan masalah

3. Siswa melakukan kajian secara independen berkaitan dengan masalah yang harus diselesaikandengan cara mencari sumber di perpustakaan,-- database, internet, sumber personāl atau melakukan observasi

4. Siswa kembali kepada semula kelompok PBL untuk melakukan tukar informasi, pembelajaran teman sejawat, dan bekerjasaman dalam menyelesaikan masalah 
5. Siswa menyajikan solusi yang mereka temukan

6. Siswa dibantu oleh guru melakukan evaluasi berkaitan dengan seluruh kegiatan pembelajaran. Hal ini meliputi sejauhmana pengetahuan yang sudah diperoleh oleh siswa serta bagaiman peran masing-masing siswa dalam kelompok.

Penelitianan mengenai model PBL pernah dilakukan oleh beberapa peneliti sebelumnya.Hasil penelitian Nurhikmah (2012) menunjukkan bahwa model PBL efektif meningkatkan kualitas pembelajaran IPA di Kelas V SD Negeri Adiwerna 04.Penelitian Nasution (2012) menunjukkan hasil bahwa adanya peningkatan belajar siswa dalam kegiatan belajar pada siklus I ke siklus II. Penelitian Muttaqin (2010) menunjukkan hasil bahwa model PBL dapat meningkatkan aktivitas dan hasil belajar siswa kelas III SD Negeri Karangmulya 02 Kecamatan Malangbong Kabupaten Garut dalam menyelasaikan soal cerita pada pokok bahasan pecahan sederhana. Penelitian yang dilakukan oleh Gallagher et al. (2002), menunjukkan hasil bahwa PBL efektif dalam membinaperkembangan siswa yang sesuai proses dan keterampilan dalam pemecahan masalah.Penelitian yang dilakukan oleh Colliver (2000), Model PBL dapat memberikan pembelajaran yang lebihmenantang, memotivasi, dan menyenangkan.

Tujuan penelitian adalahmengetahui peningkatan hasil belajar siswa, aktifitas siswa,dan respon siswamelalui penerapan model PBL (Problem Based Learning) pada mata pelajaran IPA materi energi bunyi kelas IV semester II di SDN I Sedayulawas Brondong Lamogan tahun pelajaran 2015/2016.

\section{METODE PENELITIAN}

Jenis penelitian ini merupakan Penelitian Tindakan Kelas (PTK) yang dilakukan dalam dua siklus, dimana setiap siklus terdiri dari empat tahap kegiatan yaitu (1) planning, (2) action, (3) observation, serta (4) reflection. Rancangan penelitian tindakan kelas merujuk dari Kemmis Mc. Taggart (dalam Arikunto, 2014:137) yang ditunjukkan pada Gambar 1.

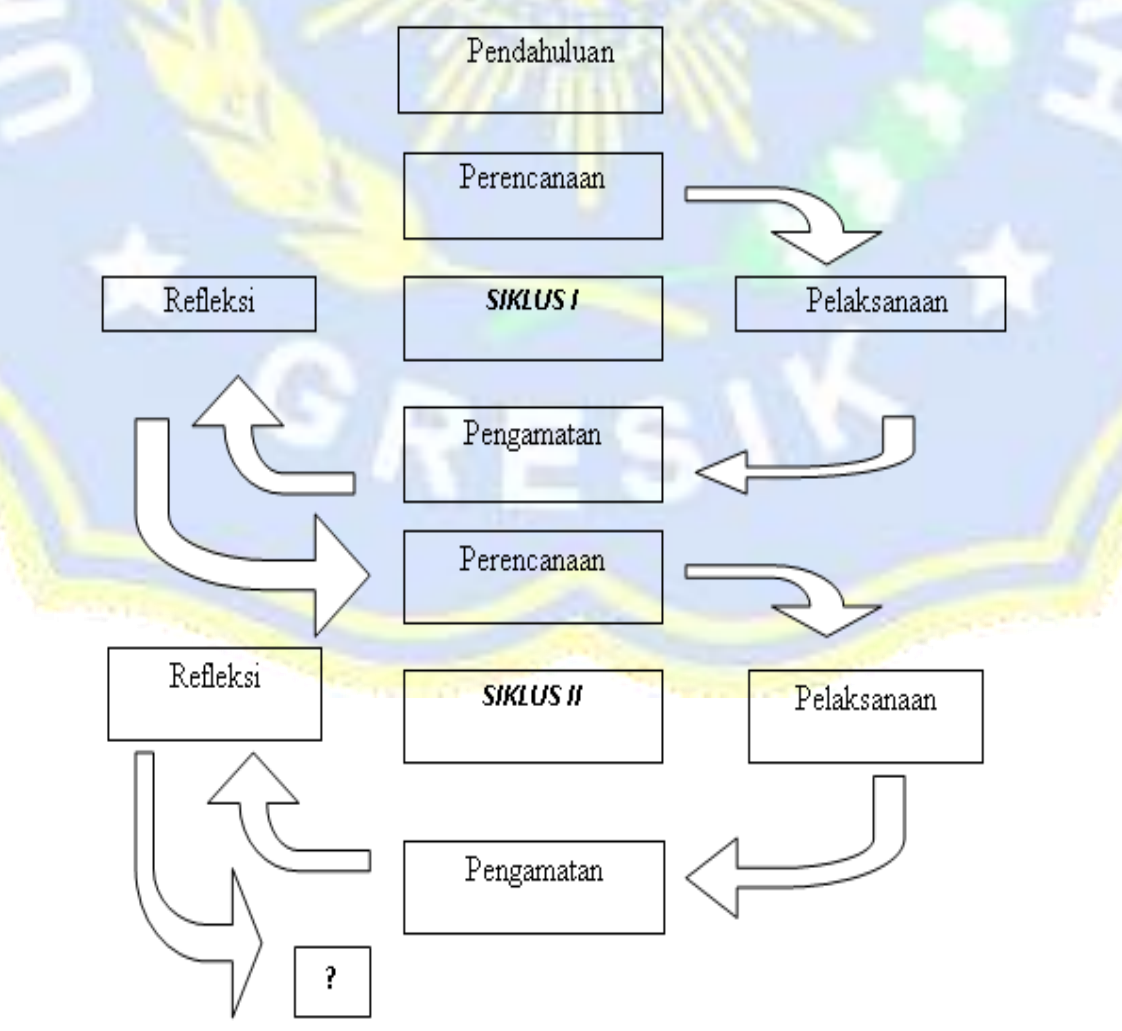

Gambar 1. Alur Penelitian Tindakan Kelas 
Penelitian dilaksanakan dengan 2 siklus. Hasil evaluasi pada siklus I masih belum tuntas, sehingga dilakukan perbaikan pada siklus II. Refleksi siklus I dilakukan untuk menentukan langkah-langkah perbaikan pada siklus II.

Subjek penelitian ini adalah siswa kelas IV SDN I Sedayulawas Brondong Lamongan Semester II Tahun Pelajaran 2015/2016 dengan jumlah 20 siswa yang terdiri dari 12 siswa lakilaki dan 20 siswa perempuan.

Instrumen yang digunakan dalam penelitian ini adalah silabus, RPP, lembar observasi pengajar,lembar observasi siswa dan angket.Sebelum digunakan sebagai instrumen penelitian, semua instrumen tersebut telah diverifikasi dan divalidasi oleh 2 validator dengan hasil validasi ahli menyatakan bahwa silabus, RPP, lembar observasi pengajar,lembar observasi siswa dan angket layak digunakan dalam penelitian dengan catatan masih dilakukan perbaikan.

Lembar evaluasi yang berupa soal tes telah divalidasi dengan hasil rata-rata validasi isi sebesar 90,27\%. Hal ini menyatakan bahwa instrument tes yang berupa soal secara konten isi layak digunakan untuk mengukur kemampuan kognitif siswa. Hasil analisi validitas butir soal menunjukkan ada empat nomor yang tidak valid karena keempat butir soal tersebut mempunyai $\mathrm{r}_{\text {hitung }}<\mathrm{r}$ table pada taraf signifikan 0,05. Butir soal yang tidak valid dilakukan perbaikan dengan menganalisis kemungkinan hal-hal yang kurang dipahami siswa berkaitan dengan soal tersebut berdasarkan saran validator.

Data dalam penelitian dilakukan dengan teknik pengumpulan data peneliti menggunakan metode dokumentasi, metode observasi, angket dan tes. Teknik dokumentasi digunakan untuk mendokumentasikan pelaksanaan penelitian berupa gambar-gambar untuk mendukung terpenuhinya sumber data yang meliputi aktivitas pengajar saat mengajar dan aktivitas siswa saat pembelajaran dan diskusi.

Analisis data berupa hasil belajar siswa dengan melihat ketuntasan belajar siswa secara individu dan klasikal. Analisis data hasil penelitian ketuntasan individu menggunakan rumus sebagai berikut :

KBI $=\mathbf{T} / \mathbf{T i} \times 100 \% \ldots \ldots($ Trianto, $2013: 171)$

\section{Keterangan :}

$\mathrm{KBI}=$ Ketuntasan belajar individu

$\mathrm{T}=$ Jumlah skor yang diperoleh

$\mathrm{Ti}=$ Jumlah skor total

Kriteria penilaian ketuntasan individu sebagai berikut.

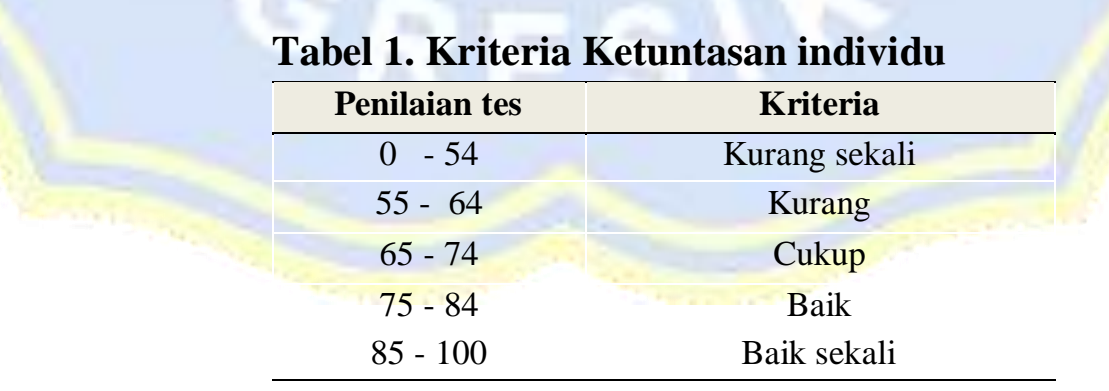

Ketuntasan belajar siswa secara klasikal digunakan rumus sebagai berikut:

Keterngan :

$\mathbf{K B K}=\frac{\boldsymbol{T}}{\boldsymbol{S}} \boldsymbol{x} \mathbf{1 0 0 \%} \ldots \ldots($ Trianto, $2013: 171)$

$\mathrm{KBK}=$ Ketuntasan belajar secara klasikal

$\mathrm{T}=$ Jumlah siswa yang tuntas

$\mathrm{S} \quad=$ Jumlah siswa seluruhnya 
Kriteria tingkat keberhasilan belajar yang dikelompokkan ke dalam lima kategori.

Tabel 2. Kriteria Tingkat Keberhasilan Belajar

\begin{tabular}{cc}
\hline $\begin{array}{c}\text { Tingkat Keberhasilan } \\
(\boldsymbol{\%})\end{array}$ & Kriteria \\
\hline$<20 \%$ & \\
$20-39 \%$ & Sangat rendah \\
$40-59 \%$ & Rendah \\
$60-79 \%$ & Sedang \\
$>80 \%$ & Tinggi \\
\hline
\end{tabular}

Siswa dinyatakan tuntas apabila dapat mencapai KKM yang telah ditetapkan sekolah yaitu 75.Sedangkan ketuntasan belajar siswa secara klasikal tercapai apabila mendapat skor minimal $80 \%$.

Analisis aktivitas siswa diperoleh selama berlangsungnya penerapan model PBL (Problem Based Learning) berlangsung.Data diperoleh dengan menggunakan lembar observasi aktivitas siswa.Data aktivitas siswa diperoleh dari lembaran observasi yang dilihat pada saat pembelajaran berlangsung, data ini dianalisis dengan menggunakan rumus persentase.Untuk mengetahui aktivitas siswa yang diamati dalam setiap pertemuan digunakan rumus sebagai berikut.

$$
\mathbf{S i}=\frac{\boldsymbol{X} \boldsymbol{i}}{\boldsymbol{N}} \times \mathbf{1 0 0 \%} \text { (Mutmainnah, 2011:32) }
$$

\section{Keterangan :}

$\mathrm{Si}=$ Persentase frekuensi aktivitas siswa

$\mathrm{Xi}=$ Frekuensi aktivitas siswa

$\mathrm{N}=$ Jumlah semua aktivitas siswa

Dengan kriteria aktivitas siswa yang dikelompokkan ke dalam lima kategori.

\section{Tabel 3. Kriteria Aktifitas Siswa}

\begin{tabular}{cc}
\hline Penilaian tes & Kriteria \\
\hline $0 \%-54 \%$ & Kurang sekali \\
$55 \%-64 \%$ & Kurang \\
$65 \%-74 \%$ & Cukup \\
$75 \%-84 \%$ & Baik \\
$85 \%-100 \%$ & Baik sekali \\
\hline
\end{tabular}

Analisis data respon siswa dilakukan dengan menyusun hasil angket dan mengubah frekuensi kedalam presentase dengan menggunakan rumusberikut:

$$
\mathbf{P}=\frac{\boldsymbol{A}}{\boldsymbol{B}} \boldsymbol{x} \mathbf{1 0 0} \% \text { (Trianto, 2013:173) }
$$

Keterangan :

$\mathrm{P}=$ Prosentase respon siswa

$\mathrm{A}=$ Prosentase jawaban tiap aspek

$\mathrm{B}=$ Banyaknya responden
Mengenai analisis data angket, Trianto (2013:123) mengungkapkan bahwa data yang telah dipersentasekan kemudian ditentukan persentase angket keseluruhan dengan mengelompokkan data berdasarkan jenis pernyataan, yaitu pernyataan positif dan pernyataan negatif, selanjutnya hasil ditafsirkan dengan menggunakan kategori persentase berdasarkan Hendro (dalamTrianto, 2013:127). 
Tabel 4. Kriteria Kateori Presentase

\begin{tabular}{cc}
\hline $\mathbf{P}(\boldsymbol{\%})$ & Kriteria \\
\hline 0 & Tak seorangpun \\
$1 \%-25 \%$ & Sebagian kecil \\
$25 \%-50 \%$ & Hampir setengahnya \\
$50 \%$ & Setengahnya \\
$50 \%-75 \%$ & Sebagian besar \\
$75 \%-100 \%$ & Hampir seluruhnya \\
$100 \%$ & Seluruhnya \\
\hline
\end{tabular}

Adapun nilai rata-rata kriteria angket respon siswa ditentukan dengan ketentuan apabila $75 \%$ dari jumlah siswa setuju pada penerapan model PBL (Problem Based Learning) yang digunakan olehpeneliti maka dikatakan penerapan pembelajaran tersebut mendapat respon positif dari siswa.

\section{HASIL DAN PEMBAHASAN}

Penelitian Tindakan Kelas ini dimulai dengan melakukan observasi pembelajaran pada kelas IV di SDN I Sedayulawas Brondong Lamongan tahun ajaran 2015/2016.Setelah dilaksanakan observasi dilanjutkan pada tahap wawancara kepada guru kelas IV di SDN I Sedayulawas Brondong Lamongan.Kegiatan ini dilakukan pada hari senin, 22 April 2016.

Berdasarkan hasil pengamatan yang dilakukan pada hari kamis tanggal 22 April 2016 terdapat beberapa permasalahan yang sedang terjadi pada kelas IV di SDN I Sedayulawas Brondong Lamongan menunjukkan bahwa siswa kurang begitu antusias selama pembelajaran berlangsung, Guru kurang menggunakan metode dan mengoptimalkan penggunaan sumber belajar seperti media dan model dalam proses pembelajaran, Guru masih menggunakan metode konvensional, Kegiatan pembelajaran_mâsih monoton, sehingga kurang menarik perhatian siswa.

Berdasarkan hasil observasi tersebut, selanjutnya peneliti melakukan diskusi dengan guru kelas IV SDN I Sedayulawas Brondong Lamongan yang bertujuan untuk memperoleh keterangan lebih lanjut tentang hasil belajar siswa dalam mata pelajaran IPA. Rendahnya nilai pembelajaran IPA ditandai dengan masih banyaknya siswa memperoleh nilai dibawah Kriteria Ketuntasan Minimal (KKM).Dengan Kriteria Ketuntasan Minimal (KKM) yang telah ditetapkan oleh pihak sekolah adalah 70 .

Kondisi awal siswa kelas IV diambil dari nilai ulangan pada materi energi bunyi. Hasil ketuntasan belajar kognitif siswa dari nilai ulangan materi energibunyi dapat dijelaskan bahwa hasil belajar pada kelas IV di SDN I Sedayulawas Brondong Lamongan pada pra siklus masih rendah. Hal ini terbukti dari nilai pra siklus hanya $37 \%$ siswa yang mencapai KKM. Berdasarkan hasil belajar kognitif , maka semua siswa yang nilainya sudah tuntas maupun yang belum tuntas tersebut perlu mendapat perhatian agar nilainya dapat meningkat dan dapat mencapai KKM. Hasil ketuntasan belajar kognitif siswa dapat dilihat pada Gambar 2.

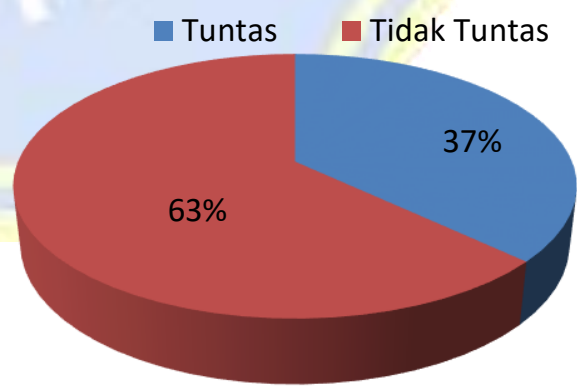

Gambar 2.Data Ketuntasan Pra Siklus 
Peneliti melakukan penelitian tindakan kelas pada siswa kelas IV SDN I Sedayulawas Brondong lamongan, dalam 2 siklus. Setiap siklusnya terdiri dari 1 kali pertemuan sehingga 2 siklus terdiri dari 2 kali pertemuan.Berdasarkan permasalahan yang telah terjadi di SDN I Sedayulawas Brondong Lamongan, maka dilakukan penerapan model pembelajaran PBL (Problem Based Learning).

Pelaksanaan kegiatan pembelajaran untuk siklus I dilaksanakan pada tanggal 25 April 2016 pada siswa kelas IV dengan jumlah siswa 20.Dalam hal ini peneliti bertindak sebagai pengajar, sedangkan guru sebagai pengamat.Peran guru dalam penelitian ini adalah pihak yang mengawasi dan menilai kinerja peneliti.

Berdasarkan hasil observasi kegiatan pelaksanaan pembelajaran siklus I diperoleh hasil
$72 \%$ kegiatan telah teramati dan $28 \%$ yang belum teramati. Hal ini disebabkan pada kegiatan membuka dan menutup pengajar dalam menimbulkan motivasi, memberi acuan, dan meninjau kembali pelajaran belum dapat diamati dengan baik.Pada model yang digunakan disebabkan oleh ketepatan model dengan tujuan pembelajaran kurang muncul dengan baik dan kesesuaian model yang digunakan dengan karakter siswa diamati kurang baik dan pada kegiatan variasi kontak mata, ekspresi, gerakan tangan, interaksi juga diamati kurang muncul dengan baik.Pada kemampuan bertanya yang kurang muncul dengan baik adalah memberikan waktu berpikir, dan pemerataan petanyaan pada siswa.

Hasil pengamatan pengajar dalam kegiatan pembelajaran siklus I diperoleh hasil sebagai berikut pada Gambar 3.

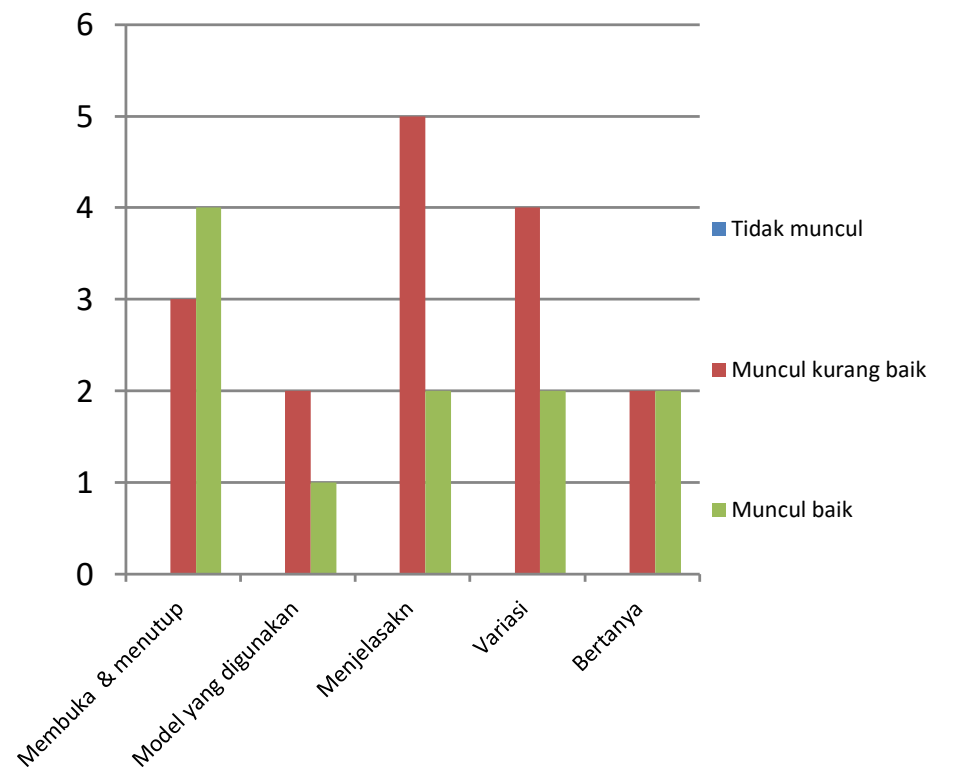

Gambar 3.Hasil Observasi Kegiatan

Pelaksanaan

Pembelajaran Siklus I

Hasil observasi aktivitâs siswa dalam kegiatan pembelajaran yang dapat diamati $75 \%$ dan yang belum dapat diamati $25 \%$. Hal ini disebabkan pada interaksi antara siswa dan pengajar, mengaitkan model dengan tugas yang diberikan, mengajukan dan menjawab pertanyaan kreativitas dari guru, mengemukakan pendapat, menjelaskan dan-mempresentasi laporan, mengomentari dan menyimpulkan proses pembelajaran diamati kurang baik.

Hasil pengamatan observasi kegiatan aktivitas siswa dalam proses kegiatan pembelajaran dapat dilihat pada Tabel 5. 


\section{Tabel 5. Hasil Observasi Aktivitas Siswa Siklus I}

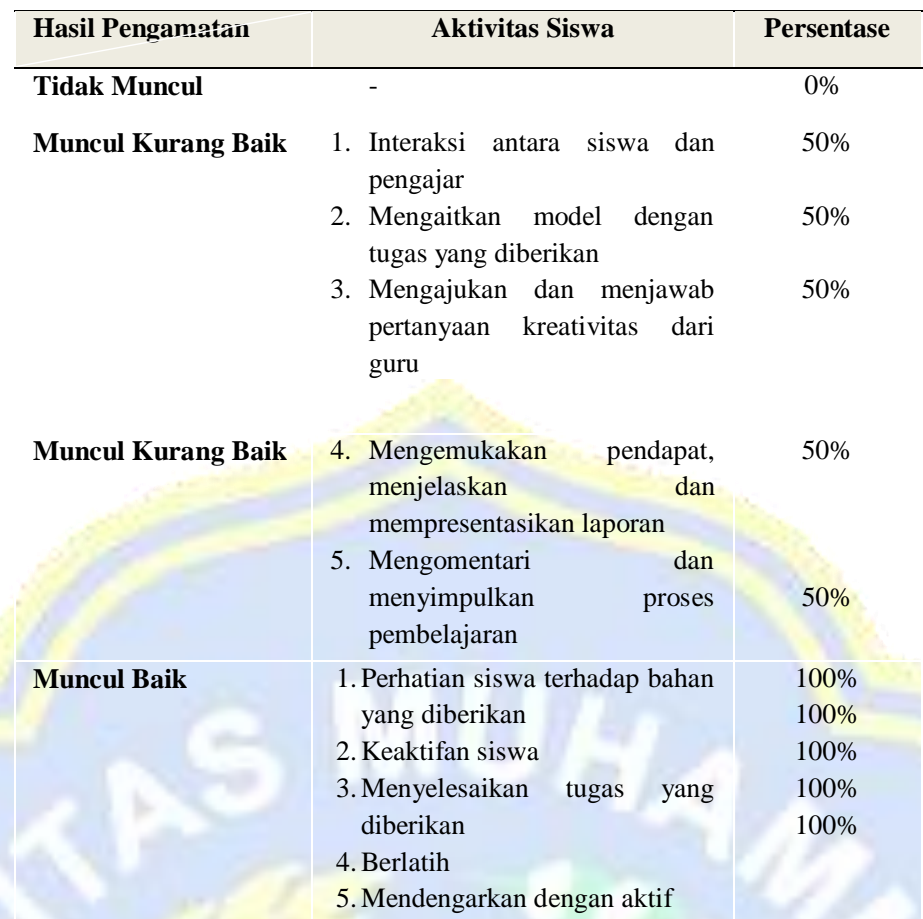

Observer menemukan salah seorang siswa tidak fokus terhadap tujuan pembelajaran yang sedang disampaikan oleh pengajar, hal ini terbukti dari hasil penyebaran angket terdapat 6 siswa yang tidak mendengarkan dan memperhatikan saat materi disampaikan, sehingga sebanyak $70 \%$ siswa yang mendengarkan dan memperhatikan pengajar saat proses pembelajaran sisanya sebanyak $30 \%$ siswa kurang antusis dengan pembelajaran yang disampaikan oleh pengajar. Selain itu juga banyak siswa yang masih belum memahami halhal yang akan dilakukannya saat mengerjakan lembar kerja siswa, ditandai dengan 4 orang siswa mengalami kesulitan saat proses pembelajaran sedang berlangsung. Kondisi tersebut juga terjadi pada saat diskusi kelompok, pengajar mendapati beberapa kelompok yang belum bisa memahami permasalahan yang diberikan oleh pengajar dan siswa masih belum termotivasi dalam merespon pertanyaan dari pengajar, sebanyak $20 \%$ siswa mengalami kesulitan saat proses pembelajaran dan 80\% diantaranya tidak mengalami kesuliatan saat proses pembelajaran. Kondisi diatas sejalan dengan keadaan siswa saat proses pembelajaran. Beberapa siswa merasa bosan saat pembelajaran IPA, ditandai dengan sejumlah 4 orang siswa merasa bosan ketika pelajaran IPA disampaikan oleh pengajar. Prosentase untuk siswa merasa bosan saat pembelajaran IPA sedang berlangsung sebanyak $20 \%$ dan sisa $80 \%$ merasa tidak bosan saat pembelajaran IPA sedang berlangsung. Hasil angket dapat dilihat pada Tabel 6. 
Tabel 6. Respon Siswa Terhadap AktivitasPembelajaran Siklus I

\begin{tabular}{|c|c|c|c|c|}
\hline \multirow[t]{2}{*}{ No. } & \multirow[t]{2}{*}{ Pertanyaan } & \multicolumn{2}{|c|}{$\begin{array}{c}\text { Jumlah respon } \\
\text { siswa }\end{array}$} & \multirow[t]{2}{*}{ Persentase } \\
\hline & & $\mathrm{Ya}$ & Tidak & \\
\hline 1. & $\begin{array}{lr}\text { Apakah kalian } & \text { mengalami } \\
\text { kesulitan saat } & \text { proses } \\
\text { pembelajaran } & \text { sedang } \\
\text { berlangsung } & \end{array}$ & 4 & 16 & $80 \%$ \\
\hline 2. & $\begin{array}{l}\text { Apakah kalian senang } \\
\text { belajar secara berkelompok }\end{array}$ & 20 & - & $100 \%$ \\
\hline 3. & $\begin{array}{l}\text { Apakah kalian senang } \\
\text { belajar menggunakan media } \\
\text { benda kongkrit dalam } \\
\text { proses pembelajaran }\end{array}$ & & - & $100 \%$ \\
\hline 4. & $\begin{array}{l}\text { Apakah kalian senang } \\
\text { dengan model pembelajaran } \\
\text { yang digunakan }\end{array}$ & 20 & - & $100 \%$ \\
\hline 5. & $\begin{array}{lr}\text { Apakah } & \text { kalian } \\
\text { mendengarkan } & \text { dan } \\
\text { memperhatikan } & \text { pengajar } \\
\text { saat menjelaskan } & \text { materi } \\
\text { yang diberikan } & \end{array}$ & 14 & 6 & $70 \%$ \\
\hline 6. & $\begin{array}{l}\text { Apakah kalian bosan saat } \\
\text { pembelajaran IPA sedang } \\
\text { berlangsung }\end{array}$ & 4 & 16 & $80 \%$ \\
\hline
\end{tabular}

Sebagai pertimbangan hasil refleksi pada kegiatan pembelajaran pada siklus I, pengajar akan menyiapkan perangkat pembelajaran yang sesuai dengan karakter siswa.

Hasil belajar kognitif dari siklus I dijelaskan bahwa hasil belajar pada kelas IV di SDN I Sedayulawas Brondong Lamongan pada pra siklus masih rendah. Hal ini terbukti dari nilai siklus I hanya $40 \%$ siswa yang tuntas dalam menyelesakan hasil belajardisiklus I. Berdasarkan nilai ulangan siklus I rata-rata tes formatif siswa 65,5 dan klasikal ketuntasan belajar siswa dalam katagori sedang. Seorang siswa dikatakan tuntas belajar apabila mencapai skor lebih dari 70 .Suatu kelas dianggap tuntas belajar apabila dikelas tersebut telah dapat mencapai lebih dari 80\%.Hasil ketuntasan belajar kognitif siswa dapat dilihat pada Gambar 4.

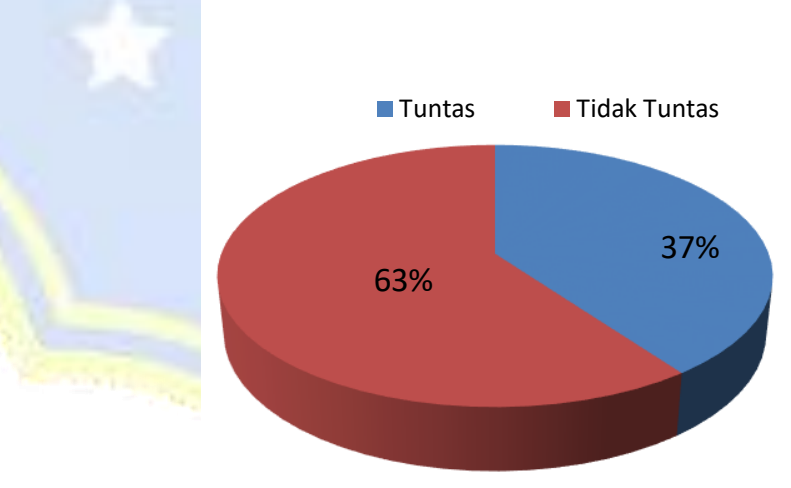

\section{Gambar 4.Data Ketuntasan Siklus I}

Berdasarkan hasil belajar kognitif, maka perlu perbaikan pada siswa yang nilainya sudah tuntas maupun yang belum tuntas tersebut perlu mendapat perhatian agar nilainya dapat meningkat dan dapat mencapai KKM.Berdasarkan, hasil belajar, hasil aktifitas siswa dan aktivitas pengajar saat pelaksanaan 
pembelajaran perlu dilakukan pembelajaran siklus selanjutnya yaitu siklus II.

Hasil siklus I mengalami peningkatan dari keadaan awal sebelum penelitian karena dengan adanya model PBL peran guru sebagai fasilitator sangat penting karena berpengaruh kepada proses belajar siswa secara berkelompok maupun secara mandiri. Hal ini sejalan dengan pendapat Yuan (2008:88) yang menyatakan bahwa PBL merupakan salah satu model pembelajaran yang menantang siswa untuk mencari solusi dari suatu masalah dari dunia nyata yang dapat diselesaikan secara berkelompok, serta PBL dapat mengarahkan siswa untuk belajar mandiri sehingga dapat mengembangkan keterampilan berpikir kritis dan dapat menganalisis masalah yang ada didunia nyata.

Walaupun siswa lebih banyak belajar mandiri tetapi guru juga memiliki peranan yang sangat penting. Peran guru sebagai tutor adalah memantau aktivitas siswa, memfasilitasi proses belajar dan menstimulasi siswa dengan pertanyaan. Hal ini sesuai dengan pendapat Barret (2005) yang menyatakan bahwa guru harus mengetahui dengan baik tahapan kerja siswa baika aktivitas fisik ataupun tahapan berpikir siswa. Namun, pembelajaran PBL masih belum maksimal karena siswa belum pernah menggunakan model PBL sehingga butuh penyesuaian dan pembiasaan dalam pembelajaran dengan menggunakan model PBL.
Siklus II berlangsung selama 2 jam pelajaran 2 x 35 menit, dengan materi pembelajaran energi bunyi. Langkah-langkah yang ditempuh peneliti dalam perencanaan ini adalah seperti pada siklus I antara lain: menyiapkan RPP, menyusun format kegiatan pelaksanaan pembelajaran dan siswa, membuat instrumen penilaian, membuat media asli dan angket yang digunakan untuk mengetahui seberapa besar respon siswa terhadap penggunaan model PBL (Problem Based Learning).

Hasil observasi kegiatan pelaksanaan pembelajaran siklus II yang dapat diamati $92 \%$ dan yang belum dapat diamati $8 \%$. Semua kegiatan dapat diamati baik akan tetapi ada beberapa indikator yang masih diamati kurang baik, diantaranya pada kegiatan membuka dan menutup yaitu meninjau kembali. Pada kegiatan menjelaskan adalah variasi dalam penyampaian, pada kegiatan bertanya yaitu pertanyaan memberikan waktu berpikir dan Pemerataan petanyaan pada siswa.Dalam siklus ini observasi guru mengalami peningkatan terhadap kegiatan pembelajaran pada awalnya kegiatan pembelajaran yang dapat diamati oleh pengamat adalah $72 \%$ menjadi $92 \%$.

Hasil pengamatan pengajar dalam kegiatan pembelajaran siklus I diperoleh hasil sebagai berikut pada Gambar 5. 


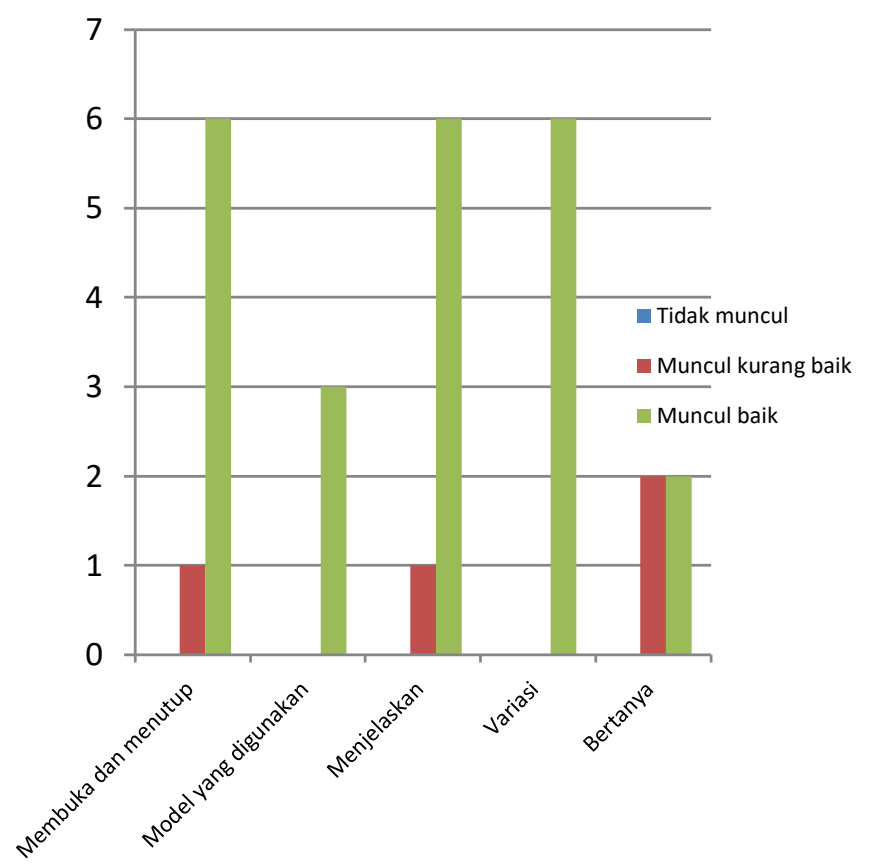

Gambar 5.Hasil Observasi Kegiatan Pelaksanaan

Pembelajaran Siklus II

Hasil pengamatan aktivitas siswa dalam dapat diamati 100\%.Hasil observasi aktivitas kegiatan pembelajaran semua kegiatan dapat siswa terdapat pada Tabel 7. diamati dengan baik, berarti semua indikator

Tabel 7. Hasil observasi aktivitas siswa Siklus II

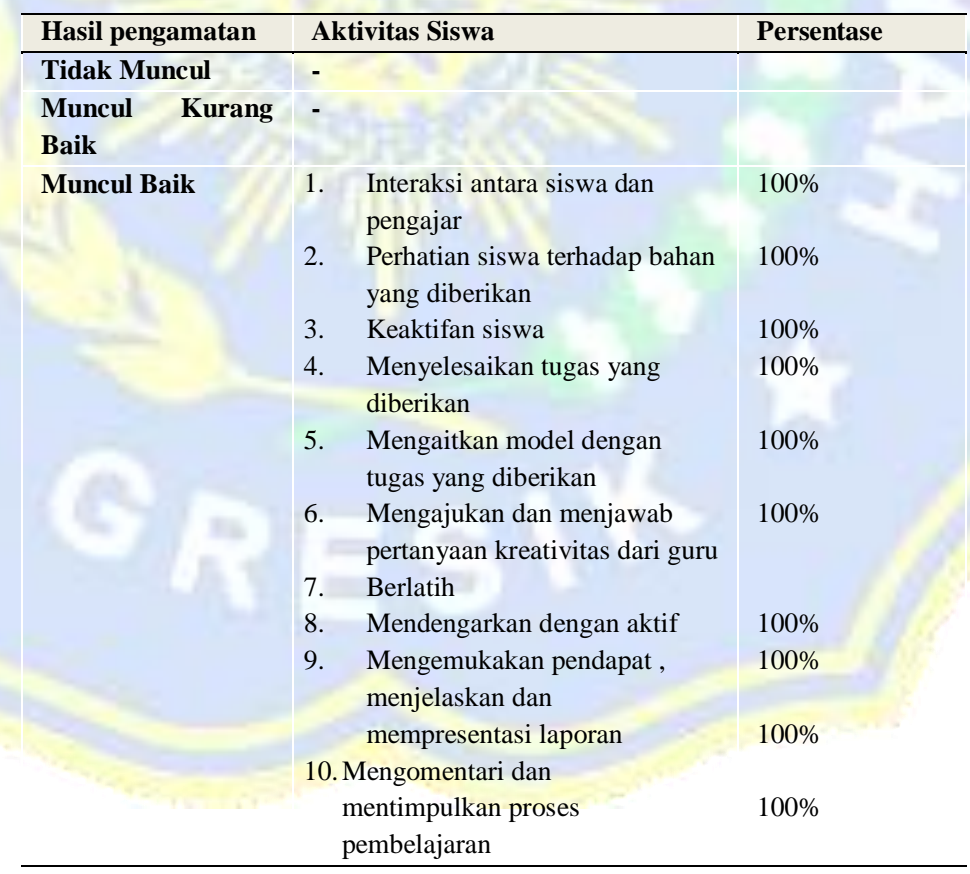

Setelah selesai proses pembelajaran dengan menggunakan model PBL (Problem Based Learning) melalui penggunaan berbagai media siswa sangat senang dan antusias mengikuti pembelajaran, hal ini dapat dilihat pada angket respon siswa yang diisi oleh siswa dengan tujuan mengetahui segala sesuatu yang terjadi ketika proses pembelajaran berlangsung.

Berdasarkan penyebaran angket pada siklus II dapat diketahui bahwa setiap siswa 
memiliki kesamaan dalam menjawab angket respon aktivitas siswa yang diberikan oleh pengajar diakhir pembelajaran siklus II, dimana seluruh siswa menjawab tidak mengalami kesulitan saat proses pembelajaran sedang berlangsung, siswa semakin memahami materi energi bunyi. Hal ini dapat dilihat ketika siswa berdiskusi dalam menemukan masalah yang telah ditentukan oleh tiap kelompok.Selain itu siswa juga merespon pertanyaan-pertanyaan dari pengajar dengan baik.Pengajar juga senantiasa memberikan umpan balik dari pertanyaan yang diberikan. Melalui penggunaan model PBL (Problem Based Learning) siswa dapat beradaptasi dengan baik dalam proses pembelajaran.Hasil angket dapat dilihat pada Tabel 8.

Tabel 8 Respon Siswa Terhadap Aktivitas Pembelajaran Siklus II

\begin{tabular}{|c|c|c|c|c|}
\hline \multirow[t]{2}{*}{ No. } & \multirow[t]{2}{*}{ Pertanyaan } & \multicolumn{2}{|c|}{$\begin{array}{l}\text { Jumlah respon } \\
\text { siswa }\end{array}$} & \multirow[t]{2}{*}{ Presentase } \\
\hline & & Ya & Tidak & \\
\hline 1. & $\begin{array}{l}\text { Apakah kalian mengalami kesulitan saat proses } \\
\text { pembelajaran sedang berlangsng }\end{array}$ & - & 20 & $100 \%$ \\
\hline 2. & $\begin{array}{l}\text { Apakah kalian senang belajar secara } \\
\text { berkelompok }\end{array}$ & 20 & & $100 \%$ \\
\hline 3. & $\begin{array}{l}\text { Apakah kalian senang belajar menggunakan } \\
\text { media benda kongkrit dalam proses pembelajaran }\end{array}$ & 20 & - & $100 \%$ \\
\hline
\end{tabular}

Lanjutan Tabel 8 Respon Siswa Terhadap Aktivitas Pembelajaran Siklus II

\begin{tabular}{|c|c|c|c|c|}
\hline \multirow[t]{2}{*}{ No. } & \multirow[t]{2}{*}{ Pertanyaan } & \multicolumn{2}{|c|}{$\begin{array}{c}\text { Jumlah respon } \\
\text { siswa }\end{array}$} & \multirow[t]{2}{*}{ Presentase } \\
\hline & & $\mathrm{Ya}$ & Tidak & \\
\hline 4. & $\begin{array}{l}\text { Apakah kalian senang dengan model } \\
\text { pembelajaran yang digunakan }\end{array}$ & 20 & - & $100 \%$ \\
\hline 5. & $\begin{array}{l}\text { Apakah kalian mendengarkan dan } \\
\text { memperhatikan guru saat menjelaskan materi } \\
\text { yang diberikan }\end{array}$ & 20 & & $100 \%$ \\
\hline 6. & $\begin{array}{l}\text { Apakah kalian bosan saat pembelajaran IPA } \\
\text { sedang berlangsng }\end{array}$ & - & 20 & $100 \%$ \\
\hline
\end{tabular}

Hasil belajar kognitif pada siklus II dapat dijelaskan bahwa hasil belajar pada kelas IV di SDN I Sedayulawas Brondong Lamongan pada siklus II mengalami peningkatan yang sangat signifikan dibuktikan dengan kettuntasan belajar siswa dalam proses pembelajaran pada siklus I secara klasikal $40 \%$ sehingga dinyatakan belumtuntas, pada siklus II setelah dilakukan perbaikan-perbaikan sehingga mengalami ketuntasan secara klasikal mencapai $85 \%$ dapat dilihat dari hasil analisis- ulangan harian dapat meningkat secara tajam. Hasil ketuntasan belajar kognitif siswa dapat dilihat pada Gambar 6. 


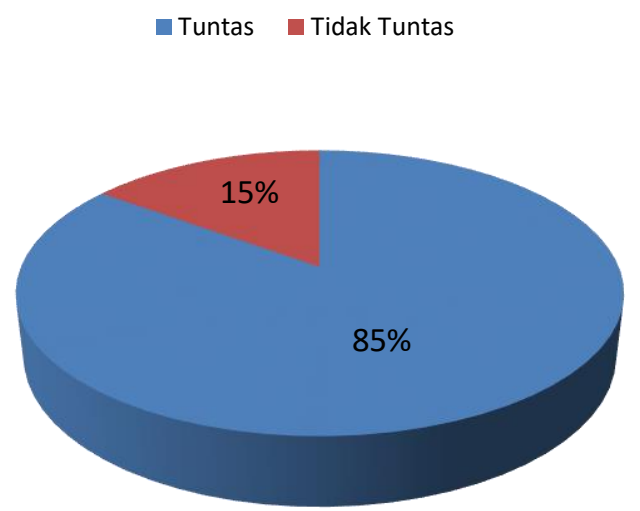

\section{Gambar 6. Data Ketuntasan Hasil Belajar Siklus II}

Peningkatan itu tidak hanya terjadi pada ulangan harian saja, tetapi dari hasil observasi pelaksanaan pembelajaran pada siklus I sebesar $72 \%$ pada siklus II sebesar 92\%. Pada hasil observasi aktivitas siswa pada siklus I sebesar $75 \%$ pada siklus II sebesar $100 \%$ sehingga dapat dinyatakan siklus II mengalami keberhasilan, dengan demikian tidak diperlukan lagi siklus III.

Peningkatan hasil belajar pada siklus II ini disebabkan oleh siswa yang telah mulai terbiasa dalam pembelajaran yang penggunaan model PBL dengan lebih menigkatkan kreativitas guru dalam mengemas proses pembelajaran, sehingga pembelajaran lebih bermakna dan menyenangkan, pengelolaan kelas dengan diskusi kelompok, dapat melibatkan keaktifan dan kreatifitas siswa lebih tinggi, dan bimbingan guru secara menyeluruh kepada siswa. Setelah selesai proses pembelajaran dengan menggunakan model PBL, siswa sangat senang dan antusias mengikuti pembelajaran. Hal ini dapat dilihat pada angket respon siswa yang diisi oleh siswa dengan tujuan mengetahui segala sesuatu yang terjadi ketika proses pembelajaran berlangsung. Hasil ini sesuai pendapat Miao et.el (200:232) yaitu guru mengatur dan menanamkan informasi kepada siswa, berbasis masalah sehinggä mendorong siswa untuk terlibat dalam aktif dan bermakna belajar. Hal ini juga sejalan dengan prinsip-prinsip dalam PBL yaitu membuat sebuah modelpembelajaran yang dapat meningkatkan belajar dengan keterlibatan aktif dalam materi pembelajaran, kerjasama antar siswa, umpan balik yang cepat, proses pembelajaran sesuai preferensi belajar siswa, danketerlibatan siswa dalam penilaian diri dan teman sekelas (Liu, 2005: 8-10). Selain itu, setelah melakukan pembelajaran model PBL, partisipasi siswa dalam belajar dapat mempengaruhipengembangan berpikir siswa dan meningkatkan keterampilan proses (Tiwariet al., (2006: 647).

Peningkatan hasil belajar siswa dari siklus I ke siklus II juga disebabkan karena siswa sudah mulai terbiasa dalam pembelajaran. Proses pembelajaran PBL ditandai dengan adanya masalah (dapat dimunculkan oleh siswa maupun guru), kemudian siswa memperdalam pengetahuannya tentang apa yang diketahui dan bagaimana untuk memecahkan masalah secara berkelompok agar saling membantu sehingga mampu berkoláborasi dalam memecahkan masalah. Melalui pembelajaran dengan model PBLmemungkinkansiswa dengan anggota kelompok

yang heterogen untuk saling bertukar pikiran, bekerjasama untuk memecahkan masalah yang pada akhirnya dapat meningkatkan kemampuan berpikir kognitifnya. Selain itu berdasarkan pendapat Curry dalam Sungur (2006: 316) mengatakan bahwa model PBL dapat menimbulkan kemampuan berpikir dan pengetahuan baru yang berguna dalam jangka panjang (long_term memori). Dengan demikian penerapan model PBL yang dilakukan dalam jangka waktu yang lama dan berulang dapat membantu siswa dalam meningkatkan kemampuan berpikir.

\section{PENUTUP}

Berdasarkan hasil analisa data dalam penelitian ini tentang penerapan model PBL 
(Problem Based Learning) pada materi energi bunyi dapat ditarik kesimpulan sebagai berikut: (1)Peningkatan aktivitas siswa melalui penerapan model PBL (Problem Based Learning) pada mata pelajaran IPA materi energi bunyi kelas IV semester II di SDN I Sedayulawas Brondong Lamongan tahun pelajaran 2015/2016 pada siklus I yang dapat diamati oleh observer sebesar $75 \%$ dengan kriteria baik dan mengalami peningkatan pada siklus II yaitu sebesar 100\% dengan kriteria baik sekali.(2) Respon siswa melalui penerapan model PBL (Problem Based Learning) pada mata pelajaran IPA materi energi bunyi kelas IV semester II di SDN I Sedayulawas Brondong Lamongan tahun pelajaran 2015/2016 mendapat respon positif ditandai dengan hasil persentase respon siswa mencapai $88 \%$ dengan kriteria hampir seluruhnya siswa setuju dengan penerapan model (Problem Based Learning) pada siklus I dan terjadi peningkatan persentase respon siswa pada siklus II dengan kriteria seluruh siswa atau $100 \%$ siswa setuju pada penerapan model (Problem Based Learning).(3)Peningkatkan hasil belajar siswa melalui penerapan model PBL (Problem Based Learning) pada mata pelajaran IPA materi energi bunyi kelas IV di SDN I Sedayulawas Brondong Lamongan tahun pelajaran 2015/2016 mengalami peningkatan ketuntasan belajar siswa dalam setiap siklus, yaitu siklus I sebesar $40 \%$ dengan kriteria ketuntasan sedang dan mengalami peningkatan pada siklus II sebesar $85 \%$ dengan kriteria ketuntasan sangat tinggi.

\section{DAFTAR PUSTAKA}

Arikunto, Suharsimi. 2014. Prosedur Penelitian Suatu Pendekatan Praktik. Jakarta: PT Bumi Aksara

Barret, Terry. 2005. Understanding Problem Based Learning. (online) . (http://www.aishe.org/ readings/2005-2/chapter2.pdf), diakses 12Oktober 2016.

Cashman,S., Seifer S.D., Unverzagt M. 2003. Advancing the Healthy People 2010 Objectives Through Community-Based Education: A Curriculum Planning
Guide.(online).

(https://depts.washington.edu/ccph/pdf_files/ handout4.pdf), diakses 29 Januari 2016.

Colliver, J. A. 2000. Effectiveness of Problem-based Learning Curricula: Research and Theory. Educating Pysicians, (online) (http//Users/Uset/Downloads/Effectiveness_o f_Problem_based_Learning Curricula_.17.pdf), diakses 12 April 2017.

Dochy, F., Segers, M., Bossche, P. V. D., \&Gijbels, D. 2003.Effects of problem-based learning: a metaanalysis. Learning and Instruction. (online) (http://www.ydae.purdue.edu/ lct/hbcu/documents/Effectsofproblem-

basedlearningameta-analysis.pdf), diakses tanggal 12 April 2017.

Gallagher, S. A. 2002. Problem-based learning: where did it come from, what does it do, and where is it going?.J. Educ. Gifted, 20(4): 332-362.

Hung, D., Jonassen, D. H., \& Liu, R. 2002. ProblemBased Learning.(online) (http://www.aect.org/ edtech/edition3/er5849x_c038.fm.pdf), diakses tanggal 10 April 2017.

Liu, Min.2005. Motivating Students Through Problem-based Learning. University of Texas

Austin.(online).(http://system.sullivan.edu/hr/ training/Training\%20Presentations/Problem \%20Based\%20Learning_Motivating\%20Stud ents\%20through\%20Problem-

Based\%20Learning.pdf), diakses 29 Januari 2016.

Maimunah. 2013. Meningkatkan Hasil Belajar Siswa pada Pembelajaran IPA dengan Menggunakan Metode Discovery di SDN 16 Taruko Lintau Buo. Jurnal Penelitian, (online) (Http://Id.Portalgaruda.Org), diakses 12 Januari 2016. 
Miao, Yongwu et.al.2000.PBL-protocols: Guiding and Controlling Problem Based Learning Processes in Virtual Learning Environment. GMD : Darmstad. (online). (http://www.umich.edu/ icls/proceedings/pdf /Miao.pdf), diakses 29 Januari 2016.

Mutmainnah.2011. Keefektifan Team Teaching dalam Pembelajaran. Jakarta: Pustaka Pelajar.

Muttaqin. 2010. Meningkatkan Kemampuan Siswa

Kelas III SDN Karangmulya 02 Kecamatan Malangbong Kabupaten Garut dalam Menyelasaikan Soal Cerita pada Pokok Bahasan Pecahan melalui Model Pembelajaran Berbasis Masalah (Problem Based Learning).Jurnal Penelitian. (online). (Http://Id.Portalgaruda.Org), diakses tanggal 10 Mei 2016.

Nurhikmah. 2012. Keefektifan Penerapan Model Pembelajaran Problem Based Learning (PBL) terhadap Peningkatan Kualitas Pembelajaran IPA Siswa Kelas V Sekolah Dasar Negeri Adiwerna 04 Kabupaten Tegal. Jurnal Penelitian. (online). (Http://Id.Portalgaruda.Org), diakses tanggal 10 Mei 2016.

Nasution F.V. 2012. Penerapan Model PBL untuk Meningkatkan Pembelajaran IPA Siswa Kelas III SD Mutiara Harapan Lawang.Jurnal Penelitian.(online).

Http://Id.Portalgaruda.Org, diakses tanggal Yuan et. al. 2008. Promoting Critical Thinking Skill 10 Mei 2016.
Peraturan Mentri Pendidikan Nasional.2008.Permen No.22,22,23 dan 24 Tahun 2006. Jakarta: Departemen Pendidikan Nasional.

Shoimin, Aris. 2014. 68 Model Pembelajaran Inovatif dalam Kurikulum 2013. Yogyakarta: Ar-ruzz Media.

Sungur, S.,\& Ceren, T. 2006. Effect of Problem Based Learning and Traditional Instruction on Self Regulated Learning. The Journal of Educational Research, 99 (5): 316.

Tiwari, A.,Lai, P., So, M., \& Yuen, K. 2006. A Comparison of the Effects of Problem-Based Learning and Lecturing on the Development of Students' Critical Thinking.Medical Education.(online).( https://www.researchgate.net/profile/Agnes Tiwari/publication/7080305_A_Comparison of the Effects_of_Problem-

Based_Learning_and_Lecturing_on the Dev elopment_of_Students\%27.

Critical_Thinking/links/55516f0308ae739bdb 921c97/A-Comparison-of-the-Effects-ofProblem-Based-Learning-and-Lecturing-onthe-Development-of-Students-CriticalThinking.pdf), diakses tanggal 10 Mei 2016.

Trianto. 2013. Mendesain Pembelajaran Kontekstual di Kelas. Jakarta: Kencana.

Wartono. 2010. Sains . Jakarta: PT. Gelora Aksara Pratama. through Problem Based Learning. CMU.Journal of Soc. Sci. And Human,2 (2): $85-100$ 